\title{
Blended Learning Program Development
}

\author{
David J. Rosen, Newsome Associates
}

The focus of the Technology Solutions for Adult Basic Skills Challenges column begins with common challenges facing adult basic skills practitioners, expressed, for example, in the LINCS Integrating Technology group for which I am the moderator, in other LINCS groups, in my national and state conference or webinar presentations, or privately in face-to-face discussions or by phone or email. Solutions to these problems, at least in part through the use of technology, include: hardware such as desktop and laptop computers, smartphones, electronic tablets, VR Goggles, and electronic whiteboards; and digital software applications such as websites, course management systems, learning management systems, databases, and apps for mobile devices. Each article begins with a challenge and examines one or more possible technology solutions.

\section{Description of the Challenge}

Blended learning is the integration of online learning with face-to-face learning. It is not just adding technology, or even adding online learning technology, to face-to-face learning, which is sometimes referred to as hybrid learning; true blended learning requires integrating face-to-face learning with online learning. Many adult basic skills programs have considered offering blended learning, and some have been trying to do it but have found that they need help with planning and program development.

\section{Possible Solutions}

In this column, I will emphasize that although choosing the right hardware and software may be important, program planning is the place to start, and I will offer two resources, available free online, that may help you anticipate and solve problems in program design for blended learning.
It's a good idea, when making a major programwide change to create a planning team, because then the implementation is more likely to meet everyone's needs: adult learners', teachers', tutors' and program administrators' needs.

Assuming your team wants to begin to offer or to improve blended learning, team members could begin by asking and answering these questions:

1. What are the teaching/learning problem(s) we are trying to solve with blended learning?

2. Why do we think blended learning will help us solve those problems?

3. Is this for some, or all, of the classes in our program? What drives this decision and how might it inform our future implementation of blended learning?

4. What are the content areas and levels of content we need in the online learning component? 
5. Do we want to obtain, or possibly purchase, a new online learning management system (LMS) or content management system (CMS), or do we plan to use an existing one?

6. Do we want the online content to be provided for us, or do we want to use a free or inexpensive Learning Management System (LMS) and find or create all our own content, or a mixture of both?

7. Do we want a feature that reports learning progress and, if so, what student learning progress information, or other kinds of information would we like it to report?

Someone on the planning team needs to take notes. If you plan a program-wide solution, circulate the notes to all your colleagues to collect their additional questions, and for clarification and refinement of answers. The team may decide that no one knows the answers to some questions, for example questions 5, 6, or 7 above, and that more information is needed, such as what the pros and cons are of these choices.

If you decide you want to purchase an online CMS, and you know what content area(s) and level(s) you need, you will find a list of some major adult basic skills education publishers that may have Content Management System products of interest at http://bit.ly/30gmBg4. If you want to find or create your own content and store it for adult learners in a free or low-cost online file storage system, you will also find in that same document lists of these storage systems and free or Open Education Resources (OER). Note that the resources listed on the document are periodically updated.

It would also be a good idea for your team to read two guides to adult basic education blended learning that will show you examples of how others are implementing it and offer you advice and resources.

\section{Blended Learning for the Adult Literacy Classroom}

If you and your colleagues are ready to act to create or improve your use of blended learning, you may find useful this link to a free, downloadable guide, Blended Learning for the Adult Education Classroom https://www.passged. com/educators/blended-learning.php or, for short, http://bit.ly/2JjOVZA. The guide, for which I am the lead author, will serve as a stepby-step road map for choosing and efficiently implementing a blended learning model that meets your needs and budget. Whether you are a beginner in blended learning, have experimented with blended learning and want to improve your skills, or you are a blended learning expert, you will find information and resources that will be worthwhile.

The guide gives an introduction to what blended learning is and how it can help you, your students, and your program; descriptions of how a wide range of adult basic skills programs (volunteer tutoring programs, ESL/ESOL, adult secondary education, and transition to college programs) are using blended learning; how you can use blended learning with your students; how to decide on an online learning platform that meets everyone's needs; and more. There is also an eight-page appendix of links to useful, mostly free, resources that you may also find helpful, including:

- Technology use surveys that you can use with your students

Computer and digital literacy skills assessments and lessons

Free online filing tools, shell platforms, learning platforms, and website builders for creating a web presence, and

Other tools and apps that are useful for adult blended learning instruction. 


\section{IDEAL Consortium Distance Education and Blended Learning handbook.}

Available free from the World Education Ed Tech Center at https://edtech.worlded.org/wpcontent/uploads/2018/08/IDEAL-Handbook6th-Edition-8-16-18.pdf, this handbook has been the core of the IDEAL Consortium foundational course called IDEAL 101 since the early days of what was first called Project IDEAL at the University of Michigan. The course supports state-level staff and program directors and key instructors with blended and distance learning program development. The current edition rests on knowledge gleaned from key research and also reflects the collective input of several distance or blended learning leaders in $\mathrm{ABE}$ programs across the country. It has a Creative Commons license so that any practitioner hoping to build distance or blended learning programs can benefit from it.

The handbook is a program development guide that helps practitioners, program directors, and other stakeholders systematically consider implementation strategies in several key areas: recruitment, screening, orientation, instruction and assessment. Within each of these areas coauthors Jen Vanek and Destiny Simpson have included descriptions of effective practice as described in reports and academic publications. They also relied heavily on first-hand accounts of successful implementation from IDEAL Consortium members. Each chapter contains descriptions of this literature and the narratives of member states' leaders. Each chapter then closes with reflective questions intended to nudge readers into consideration of program development. Source: An interview with Jen Vanek April 23 ${ }^{\text {rd }}$, 2019 in the LINCS Integrating Technology group. (https:/community.lincs.ed.gov/discussion/ interview-dr-jen-vanek-effective-practicesdistance-and-blended-learning)

\section{Reflections}

Designing and implementing a successful blended learning program is now a priority for many adult basic skills (including ESOL/ESL) programs. An effective program in which face-to-face and online learning are fully integrated is not easy or quick to create, but it can be done in small steps over time, beginning with a pilot in one or two classes. If there is an excellent online course or curriculum, then the face-to-face learning can be created to integrate and supplement that. Alternatively, if you have a successful face-toface curriculum you can design and integrate your own online supplements. If your face-toface curriculum, for example, is already built on College and Career Readiness Standards (CCRS) it is becoming increasingly easier, for example with the help of the CrowdED learning website https://www.crowdedlearning.org/ to identify free or proprietary resources to enhance the faceto-face learning. See the Technology Solutions for Adult Basic Skills Challenges column in Volume 1, Issue 1, Page 75, for more information about this: https://www.proliteracy.org/LinkClick. aspx?fileticket $=0 \mathrm{TEMdLV6sCc \% 3d \& portalid=0}$ 